\title{
Jan Rychlík, Władimir Penczew, Historia Czech, przekład Marcin Czyżniewski, Agata Kawecka, red. Ryszard Gładkiewicz, Polsko-Czeskie Towarzystwo Naukowe, Wrocław 2020, I wydanie, ss. 927
}

W jaki sposób opisać historię Czech od pradziejów do współczesności, prezentując dzieje polityczne i gospodarcze, nie pomijając jednocześnie aspektów społecznych i kulturowych? Odpowiedzi na to pytanie podjęli się dwaj wybitni badacze - czeski historyk Jan Rychlík i bułgarski bohemista Władimir Penczew w przetłumaczonej na język polski Historii Czech - pierwszej od kilkudziesięciu lat tak pełnej syntezie dziejów południowego sąsiada, która trafiła do rąk czytelników w doskonałym przekładzie oraz adaptacji tekstu dokonanej z myślą o polskim czytelniku. Minęło bowiem już wiele lat od ukazania się w 1966 r. polskiego przekładu i opracowania zbiorowej pracy - Czechostowacja ${ }^{1}$, rok później w 1967 r. książki Václava Husy Historia Czechostowacji2 oraz w 1969 r. polskiej monografii poświęconej historii Czechosłowacji autorstwa Romana Hecka i Mariana Orzechowskiego ${ }^{3}$. Polska synteza

1 Książka została opracowana i przetłumaczona przez Maurycego Kamienieckiego na podstawie wydanej w 1962 r. zbiorowej pracy Socialistické Československo. Do wersji wydanej przez Nakladatelstvi Politické Literatury, autorstwa m.in. Vladimira Forsta, Zdenka Mlynářa, wprowadzono zupełnie nowe rozdziały poświęcone polskiej mniejszości w Czechosłowacji, polsko-czechosłowackiej współpracy kulturalnej, gospodarczej oraz walorom turystycznym Czechosłowacji. Jak zaznaczono we wstępie, książka nie pretendowała do roli monografii poświęconej historii CSRS.

2 V. Husa, Historia Czechosłowacji, tłum. S. Pudysz, B. Szczucka, Praga 1967.

3 R. Heck, M. Orzechowski, Historia Czechosłowacji, Wrocław-Warszawa-Kraków 1969, narracja zbudowana na trzynastu rozdziałach od epoki kamienia doprowadzona przez autorów do dnia uchwalenia konstytucji 5 maja 1948 r.; wcześniej ukazała się praca popularyzatorki kultury i historii Czech Antoniny Smiškovej, Czechy i naród czeski, cz. 1: Opis Czech, Warszawa 1904, cz. 2: Krótka historia Czech, Warszawa 1908, poświęcona historii Czech do roku 1860, https://rcin.org.pl/dlibra/doccontent?id=504 [dostęp: 28 VII 2021]; szerzej zob. M. Jonca, 
historii wspólnego państwa Czechów i Słowaków, a następnie Republiki Czeskiej w latach 1918-2013, autorstwa Jerzego Tomaszewskiego ukazywała się w kilku wydaniach na przestrzeni lat 2006-2014 ${ }^{4}$.

Poza omawianą tu Historią Czech należy odnotować, że także w roku 2020 ukazała się publikacja autorstwa Petra Jokeša, Czesi. Przewodnik po historii narodu i państwa, która w zamierzeniu autora stanowi widzianą oczami Czechów, skierowaną do polskiego czytelnika, syntezę dziejów Czech od czasów najdawniejszych do podziału Czechosłowacji i powstania Republiki Czeskiej w 1993 r. ${ }^{5}$

Rok 2020, pomimo swojego pandemicznego charakteru, przyniósł polskiemu czytelnikowi długo oczekiwane monografie, które podobnie jak wiele dotychczasowych publikacji poświęconych dziejom Czech i Czechosłowacji w różnych okresach dziejów, określają miejsce Czech w Europie, ich kulturowe dziedzictwo i wkład w rozwój cywilizacji europejskiej. Żadna ze wspomnianych monografii nie jest efektem pracy polskich historyków, co oczywiście nie oznacza ich braku zainteresowania historią południowego sąsiada, bowiem wiele miejsca poświęcili w swoich pracach średniowiecznym dziejom państwa i społeczeństwa, wzajemnym relacjom polsko-czeskim/czechosłowackim, a po 1989 r. także trudnej powojennej historii Czechosłowacji, wprowadzając do dyskursu naukowego nowe interpretacje procesów historycznych, wiele nowatorskich ustaleń zmuszających do dyskusji i weryfikacji dotychczasowych poglądów na temat przeszłości Czech, zwłaszcza w epoce średniowiecza czy w dwudziestoleciu międzywojennym.

$\mathrm{Z}$ racji układu treści zawartość obszernej chronologicznie monografii Historia Czech przypomina znane monumentalne dzieła poświęcone historii państw i narodów. Warto przyjrzeć się strukturze pracy opartej na kryterium chronologicznym, którą tworzy siedemnaście rozdziałów poświęconych dziejom Czech, ponadto słowo wstępne od wydawcy, bibliografia a także aneksy, na które składają się: poczet głów państwa, kalendarium ważniejszych wydarzeń, indeksy - osobowy i geograficzny oraz spis map. W rozpoczynającym książkę „Słowie Wstępnym” od wydawcy okre-

Antoniny Smiszkowej Czechy dla „ludu polskiego", Literatura Ludowa 2019, nr 6, s. 8, http:// webcache.googleusercontent.com/search?q=cache:vllhgpqXPM0J:cejsh.icm.edu.pl/cejsh/ element/bwmeta1.element.ojs-doi-10_12775_LL_6_2019_001/c/LL.6.2019.001-25668. $\mathrm{pdf}+\& \mathrm{~cd}=2 \& \mathrm{hl}=\mathrm{pl} \& \mathrm{ct}=\mathrm{clnk} \& \mathrm{gl}=\mathrm{pl}[$ [ostęp: $28 \overline{\mathrm{V}} \mathrm{II} 2021]$.

4 Kilka wydań popularnonaukowej pracy poświęconej historii Czech i Słowacji po 1918 r. oraz Republiki Czeskiej do 2013 r. - zob. J. Tomaszewski, Czechy i Stowacja, Warszawa 2006; tenże, Republika Czeska 1918-2013, Warszawa 2014.

5 P. Jokeš, Czesi. Przewodnik po historii narodu i państwa, Kraków 2020. 
ślono cele syntezy dziejów Czech, wyjaśniono ciekawą genezę projektu związanego z działalnością Polsko-Czeskiego Towarzystwa Naukowego (będącego jednocześnie wydawcą książki) oraz zapoznano czytelnika z odniesieniami do poprzednich wersji Historii Czech, jak też do wcześniej publikowanych przez autorów tekstów w języku bułgarskim, czeskim i polskim ${ }^{6}$. Na uwagę zasługuje niezwykle interesujący, skłaniający do refleksji, wręcz erudycyjny, a miejscami bardzo poruszający esej autorstwa profesora Marcina Czyżniewskiego na temat sensu czeskiej historii, który można uznać za swoiste podsumowanie wywodu prowadzonego przez Autorów Historii Czech oraz wyraz osobistych przemyśleń autora eseju.

Jan Rychlík i Władimir Penczew są wybitnymi znawcami historii Czech i powodzeniem zakończyła się ich praca nad napisaniem syntezy dziejów, której podstawowym wątkiem jest zarys historii politycznej Czech i Czechosłowacji ukazany w ścisłym związku z przebiegającym równocześnie procesem przemian ekonomiczno-społecznych, ze stosunkami religijnymi i narodowościowymi oraz rozwojem czeskiej kultury.

W zamierzeniu autorów i zespołu redakcyjnego książka, która trafiła do rąk czytelników, ma do spełnienia kilka zadań. Po pierwsze - służy zaprezentowaniu polskiemu czytelnikowi historii ziem czeskich od czasów najdawniejszych po współczesność, po wtóre wskazuje na różnice w rozwoju historycznym Czech i Polski. Niewątpliwie atutem monografii jest fakt, że pozwala ona zrozumieć procesy dziejowe i uwarunkowania historyczne, które wpłynęły na rolę i miejsce, jakie zajmuje Republika Czeska we współczesnym świecie, a dzięki temu może stać się kolejnym krokiem w kierunku przezwyciężenia narosłych w przeszłości stereotypów i mitów na temat Czechów. Pozostaje postawić pytanie o to, jak szeroki będzie krąg odbiorców Historii Czech, w jakim stopniu znajdzie ona miejsce w świadomości społecznej? Autorzy, tłumacze, redaktorzy i wydawcy książki uczynili wiele, aby spełniała ona wymogi pracy naukowej przystępnej dla osób, które nie są historykami i nie posiadają specjalistycznej wiedzy. Jej odbiór przez czytelników może być dobry ze względu na spójną, logiczną i nieprzeładowaną faktami narrację, na doskonały język przekładu oraz dzięki uwolnieniu czytelnika od nadmiaru aparatu naukowego w postaci przypisów. Jest to zwięzła, przejrzysta synteza dziejów Czech uwzględniająca

6 Historia Czech ukazała się w Bułgarii w 2010 r., natomiast czeskojęzyczna wersja Od minulosti k dnešku. Dějiny českých zemí doczekała się dwóch wydań w Pradze w 2014 i 2018 r.; por. J. Rychlík, Państwo czeskie podczas wojny trzydziestoletniej, [w:] Studia Środkowoeuropejskie i Bałkanistyczne, t. 27, red. J. Machnik, I. Stawowy-Kawka, Kraków 2018, s. 37-54, w której autor informuje, że artykul jest fragmentem przygotowywanej „Historii Czech”, pierwszej nowoczesnej syntezy czeskiej historii w języku polskim. 
wspólną historię Czechów i Słowaków, którą czyta się bardzo dobrze, bez znużenia licznymi nazwiskami i wydarzeniami, ponieważ jej przekaz jest jasny i zrozumiały.

Chronologiczna rozległość tematyki monografii i jej charakter wpłynęły na to, że pewne ważne wydarzenia z punktu widzenia ziem czeskich, państwa i narodu zostały omówione przez autorów w sposób bardziej pogłębiony, inne jedynie zasygnalizowane, aby dać czytelnikowi ogólną orientację w dziejach Czech. Siłą rzeczy zabrakło w monografii miejsca na prezentację życia codziennego, mentalności, zwyczajów panujących w Czechach i Czechosłowacji, czemu może i powinna służyć odrębna monografia poświęcona historii Czechów. Niemniej jednak Autorzy, analizując procesy historyczne, nie zapominają o ich ludzkich bohaterach, o motywach i konsekwencjach ich działań.

Większość autorskich rozdziałów pracy dotyczy historii politycznej, dlatego tym bardziej warto zwrócić uwagę na te jej fragmenty znajdujące się w niemal każdym rozdziale, które zostały poświęcone czeskiej kulturze - jej rozwojowi w państwie Przemyślidów, przenikaniu się narodowych i uniwersalnych cech w średniowieczu, kulturze czeskiego odrodzenia narodowego, powstaniu kultury czechosłowackiej po 1918 r. czy jej ciekawym meandrom w okresie komunizmu.

J. Rychlík i W. Penczew nie przeprowadzają nowej interpretacji dziejów Czech, nie głoszą kontrowersyjnych sądów. Historia Czech to obraz dziejów państwa i narodu ukazany w ścisłym związku z historią powszechną, to przyczynek do poznania naszych południowych sąsiadów i do ich zrozumienia, to nie tyle obietnica, co zachęta do pogłębienia wiedzy i rozwijania zainteresowań bogatą czeską historią.

Dr hab. Anna Szczepańska-Dudziak, prof. US

ORCID: 0000-0003-4596-0956

Instytut Historyczny, Uniwersytet Szczeciński

ul. Krakowska 71/79

71-017 Szczecin

e-mail: anna.szczepanska-dudziak@usz.edu.pl

\section{Bibliografia/Bibliography}

Heck R., Orzechowski M., Historia Czechosłowacji, Wroclaw-Warszawa-Kraków 1969 Husa V., Historia Czechostowacji, tłum. S. Pudysz, B. Szczucka, Praga 1967

Jokeš P., Czesi. Przewodnik po historii narodu i państwa, Kraków 2020 Jonca M., Antoniny Smiszkowej Czechy dla „ludu polskiego", Literatura Ludowa 6 (2019), s. $3-12$ 
Rychlík J., Państwo czeskie podczas wojny trzydziestoletniej, [w:] Studia Środkowoeuropejskie i Bałkanistyczne, T. XXVII, red. J. Machnik, I. Stawowy-Kawka, Kraków 2018, s. 37-54

Smiškova A., Czechy i naród czeski, cz. 1, Opis Czech, Warszawa 1904

Smiškova A., Czechy i naród czeski, cz. 2, Krótka historia Czech, Warszawa 1908

Tomaszewski J., Czechy i Stowacja, Warszawa 2006

Tomaszewski J., Republika Czeska 1918-2013, Warszawa 2014

http://webcache.googleusercontent.com/search?q=cache:vllhgpqxPM0J:cejsh.icm.edu.pl/ cejsh/element/bwmeta1.element.ojs-doi-10_12775_LL_6_2019_001/c/LL.6.2019.00125668.pdf $+\& \mathrm{~cd}=2 \& \mathrm{hl}=\mathrm{pl} \& \mathrm{ct}=\mathrm{clnk} \& \mathrm{gl}=\mathrm{pl}$

https://rcin.org.pl/dlibra/doccontent?id=504 